\title{
ЛИНГВИСТИЧЕСКИЕ И СЕМИОТИЧЕСКИЕ ПРЕДПОСЫЛКИ ПРАВОПОНИМАНИЯ
}

\begin{abstract}
Аннотация: Статья посвящена исследованию лингвистических и семиотических предпосылок правопонимания. Цель статьи - установить, существовали ли закономерности в обозначении представлений о праве определенными символами и существовали чи закономерности в назывании понятий о разных социальных явлениях правоназваниями. В результате семиотической части исследования было выявлено, что в древнейшие времена представления о праве в форме мононорм обозначались символами, разрешаюшими или запрещающими определенное действие. Для лингвистического исследования было отобрано правоназвания в основных языках, имеющих этимологические словари. Выяснено, что исследуемые правоназвания мотивированы по значению. Первично правоназвания обозначали понятия о таких явлениях (имели такие предметные отнесенности): свобода как возможность определенного поведения, деятельности субъекта (языки осетинский, литовский); свойство того или иного явления, ставщего предметом оценивания как “справедливое-несправедливое” и признаного справедливым (языки арабский, персидский, афганский, хинди и др.); установки - внешние (разнообразные предписания, правила различного происхождения), или внутренние (его совесть, убеждения, вероисповедование и др.) относительно субъекта, способные направлять его поведение, деятельность в обществе (языки санскрит, латинский, франиузский, итальянский); установки, направляюшие человеческое поведение именно в том направлении, чтобы оно оценивалось как справедливое (языки древнегреческий, славянские, германские (в частности английский, немецкий, норвежский, голландский, шведский, датский, исландский), финский и др.); властное взвешивание интересов субъектов (китайский язык и др.). Таким образом, в правоназывании в исследованных языках состоялась объективация правопонимания, существовавщего в соответствующем языковом обществе в конкретно-исторических условиях первичных правономинационных процессов. Прослеживаются, по крайней мере, два основные типь правопонимания - «позитивистский» $и$ «естественный». В правоназваниях в некоторых языках можно усмотреть определенные модификации (комбинации) основных типов правопонимания, их интегрирование (в частности, в древнегреческом, германских, славянских и финно-венгерских языках, в которых правоназвания обозначают понятия о явлениях, способных внешне направлять поведение человека в сторону справедливости (правды)).
\end{abstract}

Ключевые слова: Внутренняя форма слова, мотивированность правоназвания, естественные языки, этимология, правоназывание, символ, мононорма, правообозначение, денотативная отнесенность правоназвания, тип правопонимания.

Abstract: This article is dedicated to the research of linguistic and semiotic perception of law. The goal of the article is to determine whether or not throughout time there have been regularities in concept of law marked by specific symbols, and whether there have been regularities in naming the notions of various social phenomena as laws. The semiotic part of the research revealed that in the ancient times the perception of law in a form of mono-norms was signified by symbols allowing or forbidding certain actions. For linguistic research, the author selected laws in main languages that have etymological dictionaries. There are at least two types of legal perception - "positivistic" and "natural". Within legal terms of some languages we can observe certain variations (combinations) of main types of legal perception, and their integration (including in ancient Greek, Germanic, Slavic, and Finno-Ugric languages, in which laws represent notions of phenomena that are able to externally influence human behavior and steer them in the right direction).

Keywords: Symbol, Law, Etymology, Natural languages, Reason for naming, Internal structure of a word, Mononorm, Markings, Denotation, Legal perception. 


\section{Право и политика 7 (187) • 2015}

ступительные замечания. Общетеоретическое исследование правопонимания посредством герменевтического инструментария предусматривает исследование семиотических и лингвистических его истоков в первую очередь. Это связано с тем, что именно знаковая репрезентация мира через человеческое сознание опосредует отношение субъекта познания к объекту понимания - явлению, отображаемому понятием права. В настоящем исследовании предлагается проверить гипотезу о том, что обозначение понятия о праве определенным знаком произошло отнюдь не случайно, а подчинялось некоторым закономерностям. В связи с этим предлагается ввести в научный оборот и определить некоторые исходные понятия. Правоназывание в естественных языках можно определить как процесс и результат закрепления за языковым знаком определенного признака понятия о практическизначимом свойстве того явления, которое является объектом правопонимания. Ради точности заметим, что термино-понятие «правоназывание» относится к этому процессу, а собственно результат последнего обозначается термино-понятием «правоназвание». Поставив вопрос о правоназывании в прошлом - до появления силлабических систем письменности, стоит оговорить понятие правообозначения, которое отображает процесс и результат обозначения древних мононорм теми или иными символами.

Уточнимтакженекоторыеметодологическиемоменты исследования правообозначения и правоназывания посредством инструментария семиотики и лингвистики. Семиотический аспект исследования предполагает необходимость соотнести процесс возникновения и эволюции мононорм с процессом письменного и звукового оформления речи для того, чтобы выяснить какие знаки и символы могли быть использованы в первобытном обществе для обозначения представлений о праве. Исходным моментом исследования выступают понятия «знак», «символ» и концепция мононорматики. Знак - сделанное человеком изображение, смысл которого известен ему и другим людям. Символ графическое изображение или поступок, с помощью которых передается определенное послание. В нашем исследовании будем вести речь о символах, поскольку для доказывания того, что мононорма была закреплена в звуковой или жетикулярной форме нужно использовать графическое подтверждение этого факта ${ }^{1}$. Мононормой

\footnotetext{
${ }^{1}$ Фоли Д. Энциклопедия знаков и символов. - М.: Вече, АСТ,
} 1997. - C. 10-11 является недифференцированное синкретическое правило поведения, которое не может быть отнесено ни к плоскости права, ни к плоскости морали, ни к плоскости этикета, поскольку оно объединяет в себе свойства любого поведения ${ }^{2}$. Использованная концепция мононорматики рассматривает нормы поведения в первобытном обществе в их эволюции, разграничивая «классический» этап и этап расслоения мононорм³

Исследование правономинационных процессов на более позднем этапе - после появления силлабических систем письменности и формирования языков - в различных языковых семьях возможно проводить только в том случае, если лексема (слово), обозначающая понятие права (правоназвание), является мотивированной. Последнее обозначает, что а) соответствующим субъектом осознается стержневая основа наименования и б) ему известна причина, почему данное значение выражено именно этим, а не другим набором звуков, т.е. именно этим словом. Ответ на вопрос о мотивированности или о немотивированности конкретного слова, обозначающего понятие о праве, следует искать именно в этимологии соответствующего слова (правоназвания). Такое исследование призвано выявить, каковы исходные значения слов, мотивировано обозначающих понятия права.

Как известно, современная лингвистическая наука разделяет все естественные языки примерно на двести языковых семей. Наиболее распространенными из них считают следующие двенадцать: индоевропейскую, семито-хамитскую, кавказскую, финно-венгерскую, самодийскую, тюркскую, монгольскую, тунгусоманьчжурскую, китайско-тибетскую, тайскую, австронезийськую, аустроазиатськую. Данное исследование правоназваний охватывает большинство упомянутых языковых семей, так как зависит от наличия этимологического словаря языков-представителей соответствующих языковых семей. Методологическую основу данного исследования составляет теория языковой номинации. Эта теория раскрывает механизмы закрепления за языковым знаком определенного понятия, выражающего денотат, то есть явление действительности, которое этим понятием отображается ${ }^{4}$.

\footnotetext{
2 Першии А. И. Проблемы нормативной этнографии. - В кн.: Исследования по общей этнографии. - М., 1979. - С. 56

${ }^{3}$ Венгеров А.Б. Теория государства и права: Учебник для юридических вузов. - М.: Юриспруденция, 2000. - С. 56

${ }^{4}$ Уфимиева А.А., Азноурова Е.С., Кубрякова Е.С. Лингвистическая сущность и аспекты номинации // Языковая номинация (общие вопросы). - М, 1977. - С. 7-98; Канделаки Т.Л. Семантика и мотивированность терминов. - М.: Наука, 1977. - 167 с.
} 
Семиотические предпосылки правопонимания. Правообозначение в первобытном обществе. Рассматривая классический этап эволюции первобытных мононорм и возможность их графического закрепления, согласимся с Ю. Семеновым в том, что на этом этапе их проявлением был табуитет как наиболее ранняя системарегулятор поведения человека, система суровых предписаний, предусматривающих наказание смертью за совершение тяжких преступлений, как например инцест, нарушение экзогамии 5 . В сферу древнейших «правоотношений», кроме табу как сакрального предписания, входили и магическо-религиозные феномены, в частности зароки, заклятия, проклятия. С мышлением человека именно в эти периоды существования первобытного общества - времена палеолита и мезолита - связывается возможность графического оформления табуитета. Археологические данные подтверждают, что в период энеолита первобытный челове делал попытки графически оформить свою речь с помощью пиктограмм - рисунков, зеркально отражающих только то, что было изображено 6 .Процесс познания первобытного челова состоял их двух этапов: «наблюдение - знание», поэтому он не мог графически отобразить представление о табу. Табу существовали только в устной форме.

На этапе расслоения мононорм началась их символизация. Этот этап связывается с эпохой становления классового общества и появой специфисеских властнорегулятивных систем. На этом этапе мононормы поддаются некоторой классификации, в частности, за способом регулирования. Кроме табу, превратившихся в запреты, Е.Черных и А. Венгеров выделяет еще и разрешения и позитивные обычаи ${ }^{7}$ Большинство ученых признают превалирующю роль именно обычаев - привычки поступать аналогично в аналогичных ситуация ${ }^{8}$. Логическое мышление человека на этапе расслоения первобытных мононорм стало развитым до такой степени, что человек уже мог сформировать представления о явлениях внешней среды и графически их отобразить с помощью символов. Процесс познания

\footnotetext{
${ }^{5}$ Семенов Ю. И. Формы общественной воли в доклассовом обществе: табуитет, мораль и обычное право // Этнографическое обозрение. - 1997. - № 4. - С. 34-38

6 Фоли Д. Указ. труд. - С. 12

7 Черных, E. H. Структура нормативной системы в древних обществах (методологический аспект) / Е. Н. Черных, А. Б. Венгеров // От доклассовых обществ к раннеклассовым / отв. ред.: Б. А. Рыбаков . - М. : Наука, 1987 . - С. 23-38

${ }^{8}$ Мальцев Г. В. Пять лекций о происхождении права и государства. - М.: Изд-во РАГС. 2000.- С. 83
}

у человека на этом этапе развития общества сосотоит из черырех звеньев: «наблюдение - логическая оценка наблюдения - практическое сравнение результатов наблюдения с дейсвительностью - знание». Таким образом средставами для графического оформления мононорм (запретов и разрешений) выступали идеограммы - рисунки, отображающие не только то, что на них нарисовано, но и другие предметы, явления, процессы, связанные с данным изображением вследствие социальной практики. Например, изображение ноги могло обозначать такие действия как стоять, идти. Таким образом, создавались объективные условия для обозначения представлений о запретах или разрешенных действиях. Можно предположить, что для обозначения запрета использовались символы, обовзначающие представления об определннных действиях, а также диактрические знаки в форме удаления сегмента из символа или в форме несечек, штрихов, отображающих спецификацию представлений об определенных действиях. Например, с помощью диактрического знака можно было указать на запрет определенных действий.

Дальнейшее развитие общества привело к усовершенствованию мышления человека, способностям мыслить умовыводами и понятиями. На этом этапе рапространены логограммы-графичекие изображения, в которых смысл слова передается с помощью одного символа. Эти символы также можно считать средствами для правообозначения. Они могли дополняться так называемыми фонетическими дополнениями символами, обозначающими комбинацию звуков. Со временем возникают и первые силлабические системы письменности, а далее в результате упрощения письменности - первая настоящая азбука, в которой один символ обозначает один гласный или один согласный звук'.

Лингвистические предпосылки правопонимания на материалах правоназваний. Право как $\boldsymbol{c} \boldsymbol{c o б о д а . ~ В ~ о д н о м ~ с л о в е ~ о б ъ е д и н е н ы ~ п о н я т и я ~ о ~ п р а в е ~}$ и о свободе в некоторых языках иранской группы (язык осетинский, слово “bar") и балтийской группы (язык литовский, слово “valé”) индоевропейской языковой семьи.

В осетинском языке понятие права обозначается словом “bar $\mid$ barae". Этимологически это слово восходит к иранскому “vāra” (желание, возможность), которое является первичным значением и формой слова "bar"; то есть генетически значение и форма слов "vāra" и "bar"

\footnotetext{
${ }^{9}$ Фоли Д. Указ. труд . - С. 13
} 


\section{Право и политика 7 (187) • 2015}

отождествляется ${ }^{10}$. Касательно формы этих слов, в частности соответствия древнеиранского „, , (в слове “vāra” (желание, возможность)) $\rightarrow$ осетинскому „b” (в слове "bar | baræ" (право) и в словах, производных от него), в этимологическом словаре осетинского языка указывается, что такое соответствие является необычным; но в данном случае правильность этимологии сомнений не вызывает, а слова с начальным „„” из „v” в осетинском языке следует рассматривать как результат влияния иранской диалектической среды, для которой такое развитие было нормальным. Таким образом, в осетинском языке в слове "bar" объединены понятия возможности (желания) и понятие права; соответственно настоящее слово содержит мотивацию, указывающую на наличие такого первичного значения в его семантическом поле как «желание», «возможность». О наличии семантической закономерности в этом слове свидетельствует сохранение его внутренней формы в производных словах, в частности: “barœj” (по собственному желанию), "barvœndonœj” (добровольно), “sœribar” (свободный), "bar daryn" (иметь право). В основу номинации всех выше перечисленных слов положен такой же признак понятия права, как то, что отражаемое им социальное явление является желанием (возможностью, свободой) субъекта совершать определенные действия или же воздержаться от совершения таких действий (самому определять свое поведение).

Право как справедливость. Объединение понятий о праве и справедливости в одном слове имеет место в арабском языке семито-хамитской языковой семьи, а также в тех языках, в том числе и других языковых семей, в которых соответствующее правоназвание было заимствовано.

Слово "haqq", обозначающее понятие о праве, первично закреплено в арабском языке, имеющем наибольшее количество носителей в семито-хамитской языковой семьи. На арабском языке написан Коран - главная священная книга мусульман, в которой собраны проповеди, обрядовые и юридические установки, молитвы, поучительные рассказы и притчи, произнесенные Мухаммедом в Мекке и Медине (VII-VIII века). Именно с последним фактом, а также с общемировой распространенностью ислама связано заимствование правоназвания из арабского языка другими языками, как в пределах семито-хамитской языковой семьи, так и языками других языковых семей. Правоназвание „haqq”, сформировавшееся в результате правономи-

${ }^{10}$ Абаев В.И. Историко-этимологический словарь осетинского языка. - М.: Изд-во АН СССР, 1958. - С. 235-236 национных процессов в арабском языке и получившее закрепление в Коране, было заимствовано языками индоевропейской языковой семьи таджикским ${ }^{11}$, афганским $^{12}$, персидским ${ }^{13}$ (иранская группа), хинди ${ }^{14}$, урду $^{15}$ (индийская группа), индонезийским ${ }^{16}$ и малазийским ${ }^{17}$ языками австронезийской языковой семьи, башкирским $^{18}$, турецким, азербайджанским, узбекским ${ }^{19}$, каракалпакским ${ }^{20}$ языками тюркской языковой семьи.

Исследуя правоназвание „haqq” посредством положений общей теории номинации попытаемся определить признаки понятия права, положенные в основу правоназывания. Биографию правоназвания „haqq” и мотивацию соответствующей правономинации попытаемся проследить сквозь призму ее закрепления в Коране. Коран - это не только книга, освящающая и утверждающая ислам - идеологию Халифата (существовавшего в Медине в довольно напряженной внутренней и внешней обстановке) как наивысшую истину - аль-хакк (слово, употребленное в Коране - T.Д.). Данная книга должна была также служить основой „правовых” установок, по которым следует «судить среди людей» и быть арабским судебником ${ }^{21}$. Таким образом, можно выделить прямое и непрямое закрепление признака понятия о праве в Коране. О прямом закреплении признака понятия права можно вести речь, когда непосредственно используется слово (результат мотивированной номинации), обозначающее понятие права в арабском языке, а соответственно одно из значений этого слова коррелирует с признаком

\footnotetext{
${ }^{11}$ Русско-таджикский словарь / Под ред. М.С. Асимова. -М.: Русс. яз., 1985. - С. 824

12 Лебедев К.А., Яиевич Л.С., Каменина З.М. Русско-афганский словарь. - М.: СЭ, 1973. - С. 550

${ }^{13}$ Восканян Г.А. Русско-персидский словарь. - М.: Русс. яз.,1986. - C. 495

${ }^{14}$ Русско-хинди словарь / Под ред. В.М. Бескровного. - М.:ГИИС, 1957. - С. 772

${ }^{15}$ Русско-урду словарь / Под ред. Зоэ Ансарии, Л.М. Помераниева. - М.: ГИИС, 1959. - С. 661

${ }^{16}$ Русско-индонезийский словарь / Под ред. Шахрула Шарифа. М.: СЕ, 1972. - С. 416-417

${ }_{17}^{17}$ Русско-малазийский словарь / Под ред. В.А. Погадаева. - М.: Русс. яз., 1986. - С. 322

${ }^{18}$ Русско-башкирский словарь / Под ред. Н.К. Дмитриева. - М.: ГИИиНС, 1954. - С. 406

${ }^{19}$ Русско-узбекский словарь / Под ред. Р. Абдурахманова. - М.: ГИИС, 1954. - С. 626

${ }^{20}$ Басканов И.А. Русско-каракалпакский словарь. - М.: СЭ, 1967. - C. 752

${ }^{21}$ Климович Л.И. Книга о Коране, его происхождении и мифологии.
} - М.:Политиздат, 1988. - С. 101 
понятия права. О непрямом закреплении признака понятия права, полагаем, речь идет, если наличие признака понятия права можно установить исходя их контекста, когда путем анализа текста Корана субъективно устанавливаются признаки понятия права, а соответственно можно установить правопонимание, закрепленное в данных признаках. Анализ текста Корана указывает на наличие такого признака понятия права как воплощение в данном понятии справедливости инструментального содержания (то есть справедливости, обеспеченной системой правосудия). Прямое же закрепление получил такой признак понятия права как справедливость идеологического содержания аль-хакк - отображение наивысшей истины.

К тому же, правоназванием „Наqq” обозначено одно из ста имен Аллаха, использованное в 92 и 199 аятах суры $3^{22}$, а также в аяте 84 суры 5 Корана ${ }^{23}$. Проанализировав указанные выше аяты, можно предположить, что у обеих упомянутых аятах суры 3 закреплены, скажем так, свойства (характеристики образа) Аллаха, в частности: в аяте 92 „Аллах („Нaqq”) богат [духовно - исходя из контекста - Т.Д.]; в аяте 199 „Аллах („Haqq”) быстрый в расчете ”. В аяте 84 суры 5 к признакам понятия „Haqq” привнесено элемент веры, а именно обосновывается необходимость веры в Аллаха („Haqq”). Полагаем, что свойства Аллаха, закрепленные в суре 3, как и необходимость верить в него целиком, покрываются таким признаком понятия о праве как справедливость с идеологическим содержательным наполнением. Именно такие свойства считались наиболее существенными для создания образа Аллаха как воплощения наивысшей истины, справедливости - аль-хакк, людям, фиксировавшим текст и читающим Коран. Таким образом, признак понятия права, закрепленный прямо - в имени Аллаха - коррелирует со значением справедливости, которое, соответственно, сохраняется как в общем имени, так и в собственном имени „(H)haqq”. Исключительно тот признак понятия о праве, который прямо закреплен, мог быть положен в основу правоназывания в связи с тем, что он общий как для опорного значения правоназвания («справедливость»), так и для ее актуального значения («право»). Поскольку такой признак понятия о праве как справедливость отображен как в собственном имени, так и в общем названии, которые являются правоназванием, это дополнительно подтверждает

\footnotetext{
${ }^{22}$ Коран / Пер. и комент. И. Ю. Крачковского. - М.: Наука, 1986. - C. $48-49$

${ }^{23}$ Там же, С. 112
}

существенность данного признака и обосновывает неслучайность положения именно этого признака в основу мотивированной номинации.

Право как установки. Объединение понятий о праве и об установках, направляющих поведение (деятельность человека), в одном слове произошло в таких праязыках как санскрит, древнегреческом и латинском, а также в романских языках индоевропейской языковой семьи.

Наиболее отдаленным в пространстве и времени от современных индоевропейских языков является праязык санскрит. В нем понятие о праве обозначается языковым знаком „ „rjüh ${ }^{24}$, мотивированным по значению и по семантической закономерности. Исходя их этимологического словаря, указанное правоназвание восходит к слову „rjüati” (обозначает такие понятия, как: «направлять», «прямой»), которое является этимоном слова ,rjủh”. То есть, генетически значение и форма слов ,rjủh” и ,rrjủati” отождествляется, поскольку в одной корневой морфеме объединено 2 понятия „прямой” и „право”. Таким образом, этимология слова „rjủh”, обозначающего понятие о праве в языке санскрит, содержит мотивацию, указывающую на наличие одного первичного значения в его этимоне - значения „направляемости”, соответственно, познанным свойством, гранью социального явления, понятие о котором обозначили словом ,r̦jủh”, было свойство этого явления направлять поведение людей в обществе.

Этимология слова "ius" (“iuris"), обозначающего понятие о праве в латинском языке, подтверждает его происхождение от слова „іuro” - „давать клятву”25. Однако первичное значение слова “ius” (“iuris”) - ,религиозная формула, имеющая силу закона (обязательную силу)" - прошло определенную эволюцию. В частности, его первично религиозный, божественный характер был со временем изменен на светский и, в конце концов, вследствие закономерных процессов развития языка за этим словом закрепилось значение позитивного права и именно последнее явление стало предметной (денотативной) отнесенностью исследуемого слова. Понятие божественного, то есть естественного права (противоположного к понятию права позитивного (“ius”, (,,iuris”)), стали обозначать другим словом “fās”. Как можно объяснить эти номинационные процессы в латинском языке? Можно предположить, что бо-

\footnotetext{
${ }^{24}$ Mayhofer M. A Concise Etymological Sanskrit Dictionary. - Bd 1. - Hdlb., 1956. - P. 121

${ }^{25}$ Ernout A., Meillet A. Dictionnaire Etymologique de la Langue Latin. - Paris, 1979. - P. 329-330
} 


\section{Право и политика 7 (187) • 2015}

жественный характер значения слова “ius” (,iuris”), а также его происхождение от „iuro” (давать клятву) обусловлены мифологическим характером мышления римлян на ранних этапах существования Римского государства, что проявлялось в их поклонении богам и обусловило необходимость узаконивания, упрочения, предоставления обязательного характера соответствующим обрядам, почестям, религиозным канонам. Таким образом, слово “ius” (,iuris”) имело первичное значение „установление, обязательность”. Поскольку этимоном слова “ius” (,iuris”) является слово „iuro”, то генетически значение и форма этих слов отождествляются: давать клятву - сказать, установить, подтвердить что-то правильное (по мнению того, кто дает клятву), обосновать поступок или суждение, которое „клятводатель” считает обязательным для себя (наверное, учитывая распространенную религиозную идеологию). Соответственно, слово ,іuro” и является опорным значением слова “ius”, которое, в свою очередь, является результатом мотивированной по значению номинации.

В соответствующем этимологическом словаре указано, что семантическая связь между словами “ius” и “iuro" далее была прервана, вследствие чего религиозный характер значения слова “ius” (,iuris”) трансформировался в светский. Не исключено, что такое изменение было обусловлено, в частности, сменой формы строя Римского государства, в частности, созданием Римской империи, в связи с чем состоялась своеобразная дерелигизация значения указанного слова. Она обусловлена политической потребностью императора в обозначении понятия о праве таким языковым знаком, который способствовал бы оправданию, „освящению” именно такого, а не иного государственного строя как едино правильного и вносил бы элемент упорядоченности, стойкости, обязательности в сформированные социальные отношения. Такая потребность и была удовлетворена путем обозначения понятия о государственно-волевом, „позитивном” праве именно словом, раньше обозначающим религиозное явление. Вместо него для обозначения права естественного, божественного начали использовать, как указано выше, другой языковой знак - „fās”. Таким образом, в латинском языке была изменена предметная (денотативная) отнесенность слова “іus”, вследствие чего семантическая закономерность, которой это слово подчинялось (а именно его связь с этимоном „іuro”), была прервана. Поэтому актуальное значение слова “ius” - ,позитивное право” - является результатом вторичной номинации. Произошло переосмысление значения слова “ius”, его перенесение на светскую жизнь без изменения при- знака, положенного в основу его первичной номинации. Вследствие того, что смысловым компонентом, перешедшим при осмыслении слова “ius” во вторичное значение, был признак, положенный в основу первичной номинации слова, можно утверждать, что внутренняя форма значения слова “іus” сохранена, а соответственно и актуальное значение слова “іus” (позитивное право) является мотивованным.

Если внутренняя форма значения слова “ius" мотивована, то производные слова, в основу которых положено корневую морфему “ius”, (а именно: iustus (справедливый, законный), iustitia (справедливость), iniurus (неправо), iudex (судья), iuramentum (решение суда)) должны содержать такой же смысловой компонент установленности, устойчивости, обязательности. Соответственно, приходим к выводу, что перевод этих латинских слов на другие языки и их использование требует уточнения; в частности, слово „іustitia” следовало бы переводить не как справедливость, а как справедливость, основанная на позитивном законе (это же касается и слова ,iustus”).

Обратимся далее к таким языкам - представителям романской языковой группы как французский и итальянский для уяснения специфики правономинационных процессов. Для обозначения понятия права во французском языке используют, как известно, слово “droit”, а в итальянском - слово “diritto”.

Упомянутое французское слово происходит от латинского "directus" 26 (прямой). Таким образом, первичное значение и форма французского слова "droit" представлена латинским словом “directus” (прямой), а соответственно генетически отождествляются значение и форма этих слов. Этимология слова “droit” coдержит мотивацию, указывающую на наличие такого первичного значения в его семантическом поле как «направляемость». В этой связи можем утверждать, что слово «directus» является опорным значением для слова «droit»- а соответственно понятия права ассоциировалось именно с признаками этого понятия, а соответствующая номинация мотивирована по значению.

С. Шевцов, ссылаясь на соответствующий этимологический словарь, указывает на то, что испанское правоназвание «derecho» также происходит от латинского этимона "directus"27.

\footnotetext{
${ }^{26}$ P.S.D. Boiste Dictionnaire Universel de la Langue Francaise, avec le Latin et les Etymologies. - Bruxelles, 1834. - P. 244

27 Шевцзов С. К пониманию права в архаичных обществах // Антропологія права: філософський та юридичний виміри (стан, проблеми, перспективи) : Статті учасників восьмого Міжнародного
} 
Слово "diritto", обозначающее понятие о праве в итальянском языке, восходит к латинскому "regere", которое и является первичным значением и формой соответствующего языкового знака ${ }^{28}$. Таким образом, генетически значение и форма слов "diritto" и "regere" отождествляется. Слово "regere" (направлять, управлять, править) выступает опорным значением для слова “diritto" - именно тем понятием о свойствах определенных социальных явлений, с которым ассоциировалось понятие о праве. Таким образом, в итальянском языке, так же как и во французском, актуальное значение правоназвания "diritto" является результатом мотивированной по значению номинации.

В итоге, в двух рассмотренных языках признаком сигнификата понятия права, положенного в основу номинации этого понятия именно соответствующими правоназваниями, является признак направленности поведения человека. Хотя этимологически оба слова восходят к разным по форме латинским, значения этих слов-этимонов аналогичны. То есть независимо от того, каким словом - "directus" или "regere" - воспользоваться при номинации понятия о праве, это слово содержало в семантике указание на такое свойство определенного социального явления, как его способность направлять поведение человека.

Право как установки, направляющие поведение человека в таком направлении, чтобы оно оценивалось как справедливое. Объединение в одном слове понятий о праве и о «справедливых установках» состоялось в древнегреческом языке, в славянских и германских языках индоевропейской языковой семьи, в некоторых языках финно-венгерской языковой семьи, а также в других языках, куда соответствующие правоназвания были заимствованы.

В древнегреческом языке индоевропейской языко-

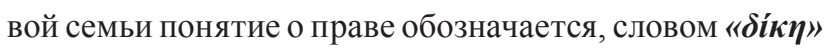
(dike). Этимологический словарь указьвает на нальчие двух первичных значений данного слова: 1) правило/ установка, обычай и 2) справедливость в человеческом аспекте. При этом указывается, что первое значений повлекло за собой второе ${ }^{29}$. То есть первичным является именно первое значение.

К несколько иному мнению пришли другие исследователи этимологии древнегреческих слов. В

«круглого столу» (м. Львів, 7-8 грудня 2012 року). - Львів : Галицький друкар, 2013. - С. 562

${ }^{28}$ Dizionario Etimologico Italiano. - Milano, 1961. - P. 240

${ }^{29}$ Chantraine P. Dictionnaire étymologique de la langue grecque. Histoire des mots. - Tome 1 A- $\Delta$ частности, С. Шевцов, ссылаясь на Э. Бенвениста и П. Шантреина, утверждает, что в основе - корень со значением «класть, устанавливать». А почему термин, обозначающий внешнюю формальную процедуру, порождает понятия, относящиеся к совершенно иному полю (справедливости), остается загадкой ${ }^{30}$.

Детальное исследование развития понимания термино-понятия «дике», а также эволюции значения соответствующего слова в связи с развитием его понимания в этом языке провела в свое время Д. Луковская ${ }^{31}$. В этом исследовании была ярко продемонстрирована мотивированность слова „dike”, а соответственно и неслучайность такого правоназывания в греческом языке. В этом исследовании детально аргументируется наличие такого первичного значения слова „dike” как «правда», «справедливость».

Таким образом, отсутствует единое мнение касательно первичного значения древнегреческого правоназвания. Найболее убедительной, на наш взгляд, является этимология древнегреческого правоназвания, представленная в соответствующем этимологическом словаре, а соответственно первичными значениями правоназвания „dike” являются значение правила/установки и справедливость. Соответственно, установление денотативной отнесенности правоназвания требует их интегрирования. На наш взгляд, правоназвание в древнегреческом языке обозначало именно правила, установки, которые оценивались как справедливые.

Слово «право» возникло и используется как правоназвание в славянской языковой группе (языки древнерусский, русский, украинский, белорусский, болгарский, сербохорватский, словенский, чешский, словацкий, польский) индоевропейской языковой семьи. В процессе исторического развития данное правоназвание было заимствовано в следующие языки: кабардино-черкесский ${ }^{32}$ кавказской языковой семьи, ногайский ${ }^{33}$, хакасский ${ }^{34}$, якутский ${ }^{35}$ тюркской языковой

\footnotetext{
${ }^{30}$ Шевцов С. Указ. труд. - С. 554-555

31 Луковская Д.И. У истоков правовой мысли Древней Греции // Известия высших учебных заведений. Серия: "Правоведение". 1977 - №1 . - C.75-84

32 Русско-кабардино-черкесский словарь / Б.М. Карданов, А.Т. Бичоев. - М.: СЄ, 1955.- С. 403

${ }_{33}$ Русско-ногайский словарь / Под ред. Баскакова И.А. - М.: Гос. изд-во иностр. словарей, 1956. - С. 462

${ }^{34}$ Русско-хакасский словарь / Под ред. Д.И. Чанкова. - М.: Гос. изд-во иностр. словарей, 1961. - С. 653

${ }^{35}$ Русско-якутский словарь / Под ред. П.С. Афанасьева, Л.Н. Харитонова. - М.: СЭ, 1968. - С. 471
} 


\section{Право и политика 7 (187) • 2015}

семьи, марийский ${ }^{36}$ финно-венгерской языковой семьи, эвенкийский тунгусо-манчжурской языковой семьи, корякский ${ }^{37}$ чукотско-камчатской группы палеоазиатской языковой семьи. Вышеупомянутые заимствования славянского правоназвания в языки разных языковых семей обусловлены внешними, а не внутренними причинами, в частности - контактированием языков. Помимо этого, отдельно обозначим то обстоятельство, что чуть ли не все языковые общности, в языках которых произошли заимствования славянского правоназвания, входили в состав народов СССР. Полагаем, именно этот фактор привел к тому, что в языках разных семей на современном этапе используется одно и то же правоназвание с корнем «прав».

Этимологически, как свидетельствуют соответствующие словари, оно восходит к слову *pravb (см. пра́вый, прав (русс.); пра́ви́й (укр.)) - «противоположный левому; справедливый; прямой; [перпендикулярный]», является этимоном (первичным значением и первичной формой) слова «право» ${ }^{38}$; то есть генетически значение и форма слов „право” і „правый” отождествляется. Так, П. Стучка, ссылаясь на П. Лафарга, объяснял такую этимологию слова “право” тем, что “... объединение в одном слове понятий прямой и право связано с первичным измерением земли"з9, и, как следствие, обосновывал происхождение данного слова из экономических отношений, С. Алексеев склоняется к этическому происхождению языкового знака “право”40. Соответственно, этимология слова „право” в славянских языках содержит мотивацию, указывающую на наличие двух первичных сем в его значении: “прямой” (отсюда - “править”, “направлять”) и “справедливость” (правда). Соответственно, понятием права отражено общественное явление, имеющие свойство «направляемости» (в значении “направления”, “правления”) и свойство «справедливости». Интегрировав оба значения в слове “право”, можем предположить, что оно указывает на денотат “mо, что направляет в сторону справедливости, правды”. Несмотря на та-

\footnotetext{
${ }^{36}$ Русско-марийский словарь / Редкол. И.С. Ралкин (главред). - М.: СЭ, 1966.- С. 562

${ }^{37}$ Жукова А.Н. Русско-корякский словарь. - М.:СЭ, 1967. - С. 168

${ }_{38}$ Фасмер М. Этимологический словарь русского языка: Т. 3. - М., 1987. - С. 352; 656с.; Етимологічний словник української мови: Т.4 - К.: Наук.думка, 2003. - С. 350-351

${ }^{39}$ Стучка П. Классовое государство и гражданское право / Coциалистическая академия. Секция права и государства. - М., 1924. - C. 13

40 Алексеев С.С. Проблемы теории права: Т. 1. - Свердловск, 1972. - С. 30
}

кую предметную отнесенность слова “право”, в основу его номинации - в соответствии с лингвистическими правилами техники номинации - полагалась одна сема (значение) этимона “правый” как опорного значения; пока за этим понятием не закрепились оба значения.

В языках германской языковой группы индоевропейской языковой семьи пользуются правоназванием, функцию которого исполняет слово, заимствованное с латинского языка. К таким языкам относятся: датский (слово “ret”), шведский (слово “ratt”), норвежский (слово “rett”), исландский (слово “rett”), английский (слово “right”), голландский (слово “recht”), немецкий (слово “Recht”). Учитывая, что во всех перечисленных языках используются заимствованное из одного праязыка правоназвание, рассмотрим детальнее только два.

В английском языке существуют два слова для обозначения понятия о праве: „right” (слово, обозначающее понятие о субъективном праве) и “law" (обозначает понятие об объективном праве - о законе или прецеденте). Отметим, что данный анализ касается именно слова „right” в связи с тем, что основное значение слова "law" - «закон».

В немецком языке понятие о праве обозначается словом “recht". Рассмотрим «биографию» обоих слов целостно в связи с тем, что как свидетельствуют соответствующие этимологические словари, слова „right” и “recht" восходят к одному и тому же этимону, поскольку они заимствованы из латинского языка - праязыка, в частности, для языков германской языковой группы ${ }^{41}$. Первичными значением и формой относительно заимствованных слов являются два слова "rectus" (прямой, направлять) и “regere" (управлять, править). При этом в этимологических словарях отсутствует объяснение, почему оба слова - „right” и “recht” - восходят одновременно к обоим латинским словам (“rectus” (прямой, правильный) и "regere" (направлять, управлять, править)). Указано только, что двойное значение (бисемия, (double sence) „прямой” (straight) и „справедливый” (just)) как слова „right”, так и слова “recht” распространяется и на другие слова, обозначающие понятие права во всех языках данной языковой группы. Такое значение обоих слов как «противоположный левому» появилось позже, а первичными для них являются семы направляемости и справедливости.

Таким образом, в языках германской языковой семьи, к примеру, в английском и в немецком языках, использована такая разновидность правоназывания, ${ }^{41}$ The Concise Oxford Dictionary of English Etymology. / Edited by
T.F. Hoad. - Oxford, 1993. - P. 405; Etymologishes Wörterburh Der
Deutshen Sprache / bearbited von Walter Mitzka. - Berlin, 1957. - P. 588 
когда слово, обозначающее понятие о праве, «унаследовало» семы двух слов с праязыка и при этом этимону данного слова свойственна бисемия, которая, соответственно, распространялась как на это слово, так и на производные слова.

В финно-венгерской языковой семье существует несколько употребляемых правоназваний - как заимствованных из индоевропейских языков, так и автохтонных, «родных» для нее. Обратимся, прежде всего, к правоназванию “igaz”, которое, по утверждению этимологов, является наиболее древним, возникшим в венгерском языке данной языковой семьи и упоминается в наидревнейших памятниках этого языка. Сам же венгерский язык является наиболее древним из уральских языков (языков финно-венгерской языковой семьи), поскольку его письменность сформировалась приблизительно 1250 лет назад. Соответственно, данное правоназвание было звуковой формой для обозначения двух понятий - о праве и правильности ${ }^{42}$. Однако сейчас в венгерском языке используется правоназвание «jog», этимология которого весьма неоднозначна. В соответствующем словаре укзавается возможность его происхождения от китайского “уо”- «обязывать», рассмотренного вище арабского “hak" - «право, справедливость» ${ }^{43}$. Вопрос о присхождении этого правоназвания не вполне ясен.

С большей степенью вероятности можно анализировать первичные значения правоназвания "oikea", обозначающего понятия права в финском языке. Заимствование данного правоназвания произошло в мордвинском и черемисском языках этой же языковой семьи. Биография данного слова свидетельствует о наличии таких его первичных значений как 1) „правильность”, „справедливость” и 2),,направляемость”. То есть, правоназванием "oikea” объединены понятия о праве, справедливости и направляемости. Сама же форма этого правоназвания является первичной, а значит, не происходит от другого слова.

Опираясь на положения общей теории номинации, можно утверждать, что значения 1) „правильность”, „справедливость”, 2) „направлять” являются опорными значениями к значению "право" - а соответственно именно тем понятием об определенных свойствах некоторых социальных явлений, с которыми ассоциировалось понятие права. Таким образом, актуальное

${ }^{42}$ Björn Collinder Fenno-Ugric Vocabulary. An Etymological Dictionary of the Uralic Languages. - Stockholm: Almqvist \& Wiksells; Upplasa, 1953. - P. 103

${ }^{43}$ Alfred Toth Etymological Dictionary of Hungarian (EDH). - Hague: Mikes International, 2007. - P. 516, 642 значение слова "oikea" является результатом мотивированной по значению номинации. Другими словами, данные понятия полагались в основу номинации по очереди; в конце концов, они оба закрепились за данной звуковой формой. Таким образом, в финском языке финно-венгерской языковой семьи (а также в других языках данной языковой семьи, в которых применяют это правоназвание) присутствует бисемия опорного значения, так же, как и в правоназывании в славянских и германских языках.

Проследив этимологию слова "oikea" в финских языках, приходим к выводу о том, что оно указывает на денотат “то, что направляет в сторону справедливости, правды".

Право как результат властного взвешивания, балансирования интересов людей. Объединение понятий о праве и о властном балансировании интересов в одном слове произошло в китайском языке китайскотибетской языковой семьи и заимствовано в японский язык дальневосточной языковой семьи.

В китайском языке понятие о праве обозначается правоназванием “quánlì”. Как известно, письменность китайского языка иероглифическая, логографическая. Наиболее древние ее памятники датируются второй половиной ІІ тыс. до н.э. Учитывая древность этого языка и сохранение его в относительно древнем состоянии (в частности в виде логографической письменности, первично существовавшей во всех языках), исследование правоназвания в данном языке особенно интересно.

Выше упомянутое правоназвание “quánli” включает два иероглифа - “quán” и “lì,, то есть является двухскладным ${ }^{44}$. Правоназвание “quánli” не принадлежит к наидревнейшим хотя бы в связи с двухскладностью; на иероглифе “quán”, как свидетельствует словарь китайского языка, отразились процессы сокращения иероглифов, вследствие чего его форма является упрощенной; далее мы будем вести речь исключительно о графеме иероглифа “quánli”, поскольку фонемы каждой из обеих его частей (иероглифов “quán” и ”li”), „не отвечают" за правономинацию.

Первичным значением слова “quán” является „гиря” (для весов), и „взвешивание”, а первичным значением слова “li” является „интерес" ${ }^{45}$. Соответственно, объединение с целью номинации - графем “quán” и

\footnotetext{
${ }^{44} \mathrm{~B}$ целях упрощения обозначения правоназвания будем использовать не иероглифы, обозначающие понятия права, а их латинобуквенную транскрипцию, представленную в соответствующем словаре.

${ }^{45}$ Китайско-русский словарь. - [Пекін: Шанхайський інститут іноземних мов], 1990. - С.550-551; Русско-китайский и китайскорусский словарь. - М.: Русс. яз., 1999. - С. 103
} 


\section{Право и политика 7 (187) • 2015}

"li" произошло для обозначения нового обозначаемого - понятия права. Такая разновидность номинации принадлежит к первичным номинационным прочессам, поскольку для обозначения нового обозначаемого (понятия права) в акте номинации не использовалась уже существующая языковая единица, а была создана новая. Номинация понятия права в китайском языке состоялась путем объединения двух слов, выступивших опорными значениями для актуального значения „право" соответствующего правоназвания. Поэтому установление признака, который полагается в основу номинации понятия права словом “quánlì, требует интегрирования обоих указанных опорных значений, их, скажем так, «сплавления» в один признак. Опираясь на вышеизложенное, можем констатировать, что познанным свойством, атрибутом определенного социального явления, отображенным в признаках понятия права, обозначенного правоназванием в китайском языке, является способность данного явления взвешивать интересы лиц. Именно это и составляет предметную отнесенность слова “quánli” в китайском языке. Заметим также, что семантике слова “quán” свойственны, так сказать, проявления, симптомы „властности”, поскольку другим значениям этого слова (значение „взвешивания” является первичным), а также производным двухскладным словам в китайском языке свойственна лишь «властная» окраска. Учитывая вышеизложенное, можно уточнить положением о том, что признаком, положенным в основу номинации понятия права словом “quánli”, является отражение способности определенного социального явления властно взвешивать интересы лиц.

Понятие о справедливости, скорее всего, не ассоциировалось с понятием права, поскольку эти понятия обозначаются разными иероглифами (в частности: „право” - иероглифом “quánli”, и „справедливость”иероглифом „zhéngyi”. Производными от последнего также являются „zhéngli”, ,zhénghua” (правильный) и „zhéngshi”, ”shi” (истинный). Поскольку оба эти иероглифа являются двухскладными, не представляется возможным определить, которое из соответствующих слов является более древним. В отличие от большинства языков мира - в наидревнейшем - китайском - не закреплено такое первичное значение правоназвания, в которое было бы органически «вплетено» признак справедливости (однако это не исключает возможность оценки результата взвешивания интересов лиц как справедливого или несправедливого). Не исключено, что это можно объяснить конкретно-исторической спецификой развития общества и государственности в
Китае, высоко значимой ролью правителя, необходимостью в могущественной централизованной власти для осуществления управления страной, наличием сильной династийной власти ${ }^{46}$. Да и специфика философского мировоззрения древних китайцев также оставила след в правоназвании. Историки также указывают, что «только на китайскую правовую систему влияли два противоположных учения. Этико-политические догматы конфуцианства («ли») и политико-правовые концепции легизма («фа») стали определяющими для развития права, его идейных основ, принципов и институтов, традиционного правопонимания китайцев ${ }^{47}$ ».

Нет необходимости выделять в самостоятельный предмет исследования правономинационные процессы в дальневосточной языковой семье, поскольку они основаны на заимствовании правоназвания с китайского языка.

Общие выводы. 1. В первобытном обществе объективно существовали необходимые предпосылки для графического закрепления мононорм на втором этапе их развития. Для обозначения представлений о мононормах в форме запретов, разрешений использовали символы для обозначения определенных действий, в том числе и диактрические или фонетические дополнения к ним. В этом и можно усматривать закономерность и специфику именно правообозначения в сравнении с обозначением других явлений.

2. Правоназвания в около 50 исследованных языках мира во время номинационных процессов обозначали представления и понятия о таких явлениях:

- свобода как возможность определенного поведения, деятельности субъекта (языки осетинский, литовский);

- свойство того или иного явления, которое стало предметом оиенивания как "справедливое/несправедливое” и было признано справедливым (языки арабский, персидский, афганский, хинди, а также те, в которые соответствующие правоназвания были заимствованы);

- установки - внешние относительно субъекта (разнообразные предписания, правила различного происхождения), или внутренние (его совесть, убеждения, вероисповедование и др.), способные направлять его поведение, деятельность в обществе (языки санскрит, латинский, французский, итальянский, испанский и др.);

- установки, направляющие человеческое поведение именно в том направлении, чтобы оно оченивалось как справедливое (языки древнегреческий, славянские, гер-

\footnotetext{
${ }^{46}$ Крашенинникова Н.А. История права Востока: Курс лекций. - М.: Изд. Российского открытого ун-та, 1994. - С. 46-47

${ }^{47}$ Там же. - C. 47
} 
манские (в частности английский, немецкий, норвежский, голландский, шведский, датский, исландский), финский, а также те, в которые соответствующие правоназвания были заимствованы);

- властное взвешивание интересов субъектов (китайский язык, а также те языки, которые позаимствовали китайское правоназвание).

3. В тех языках, где в основу правоназывания положен такой признак определенного социального явления как справедливость, произошло “вплетение” этого признака в структуру сигнификата понятия об определенном социальном явлении. Ведь справедливость сама по себе не является отдельным, “автономным” явлением социальной действительности, а составляет лишь свойство, атрибут тех или иных явлений (в том случае, если она отображена в признаке, положенном в основу мотивированной номинации понятия о праве). Такое свойство приписывается им на основании оценочного познания их значимости (иными словами, характера, содержания их воздействия) для жизнедеятельности отдельных субъектов. Как следствие, справедливость (или же, наоборот, несправедливость) не является сама по себе самостоятельной предметной отнесенностью понятия, поскольку в качестве последней в данном случае выступает как раз то явление, которому свойственна именно такая значимость - “справедливая” (то есть позитивная, полезная) или же, наоборот, “несправедливая" (то есть негативная, вредная).

4. В процессе исторического развития общества, разнообразие социальной практики и расширение социального опыта привели к семантическому обогащению сигнификативного значения правоназваний. Обозначение правоназванием понятий про иные социальные явления открыло новый этап в развитии правоназывания - терминологизацию правоназвания. Данный процесс сопровождался увеличением количества явлений (или их свойств), обозначаемых правоназванием. Так, в рамках позитивистского правопонимания понятием права стали отображаться такие явления как юридическая (государственная) норма, решение суда; в рамках психологического - индивидуальная воля субъекта, индивидуальное признание, чувства и эмоции субъекта и другие явления индивидуальной психики, а также воля господствующего класса как проявление психики коллективной; в рамках социологического правопонимания - общественные отношения, потребности и интересы (как осознанные потребности) субъекта.

5. В правоназывании в исследованных языках состоялась объективация правопонимания, существовавшего в соответствующем языковом сообществе в конкретно-исторических условиях первичных правономинационных процессов. Более того, можем констатировать, что в правоназывании в том или ином из исследованных языков отображаются по крайней мере два основные типы правопонимания, впоследствии названные «позитивистским» и «естественным». К естественному правопониманию можно отнести и правоназвания, обозначающие понятие о свободе. В правоназваниях в некоторых языках можно усмотреть определенные модификации (комбинации) основных типов правопонимания, их интегрирование (в частности, в древнегреческом, германских, славянских и финно-венгерских языках, в которых правоназвания обозначают понятия о явлениях, способных внешне направлять поведение человека в сторону справедливости (правды)). Тем самым проявляется историческая первичность именно этих - естественного и позитивистского типов правопонимания. И обусловлена она, в первую очередь, определенными объективными закономерностями развития общества.

\section{Библиография:}

1. Alfred Toth Etymological Dictionary of Hungarian (EDH). - Hague: Mikes International, 2007. - 792 p.

2. Björn Collinder Fenno-Ugric Vocabulary. An Etymological Dictionary of the Uralic Languages. - Stockholm: Almqvist \& Wiksells; Upplasa, 1953. - 546 p.

3. Chantraine P. Dictionnaire étymologique de la langue grecque. Histoire des mots. - Tome 1 A- $\Delta-$ Paris: Klinksieck, $1968 .-1387$ p.

4. Dizionario Etimologico Italiano. - Milano, 1961. - 340 p.

5. Ernout A., Meillet A. Dictionnaire Etymologique de la Langue Latin. - Paris, 1979. - 434 p.

6. Etymologishes Wörterburh Der Deutshen Sprache / bearbited von Walter Mitzka. - Berlin, 1957. - 1012 p.

7. Mayhofer M. A. Concise Etymological Sanskrit Dictionary. - Bd 1. - Hdlb., 1956. - 975 p.

8. P.S.D. Boiste Dictionnaire Universel de la Langue Francaise, avec le Latin et les Etymologies. - Bruxelles, 1834. - 687 p.

9. The Concise Oxford Dictionary of English Etymology. / Edited by T.F. Hoad. - Oxford, 1993. - 545 p.

10. Абаев В.И. Историко-этимологический словарь осетинского языка. - М.: Изд-во АН СССР, 1958. - 350 с

11. Алексеев С.С. Проблемы теории права: Т. 1. - Свердловск, 1972. - С. 30; 395с.

12. Басканов И.А. Русско-каракалпакский словарь. - М.: СЭ, 1967. - 1124c. 


\section{Право и политика 7 (187) $\bullet 2015$}

13. Венгеров А.Б. Теория государства и права: Учебник для юридических вузов. - М.: Юриспруденция, $2000 .-528$ с.

14. Восканян Г.А. Русско-персидский словарь. - М.: Русс. яз.,1986. - 832c.

15. Етимологічний словник української мови: Т.4 - К.: Наук.думка, 2003. - 656c.;

16. Жукова А.Н. Русско-корякский словарь. - М.:СЭ, 1967. - 749с.

17. Канделаки Т.Л. Семантика и мотивированность терминов. - М.: Наука, 1977. - 167 с.

18. Китайско-русский словарь. - [Пекін: Шанхайський інститут іноземних мов], 1990. - 787 с.;

19. Климович Л.И. Книга о Коране, его происхождении и мифологии. - М.:Политиздат, 1988. - 298c.

20. Коран / Пер. и комент. И. Ю. Крачковского. - М.: Наука, 1986. - 298 с.

21. Крашенинникова Н.А. История права Востока: Курс лекций. - М.: Изд. Российского открытого ун-та, 1994. - 121с.

22. Лебедев К.А., Яцевич Л.С., Каменина 3.М. Русско-афганский словарь. - М.: СЭ, 1973. - 872c.

23. Луковская Д.И. У истоков правовой мысли Древней Греции // Известия высших учебных заведений. Серия: “Правоведение”. - 1977 - №1. - С.75-84

24. Мальцев Г. В. Пять лекций о происхождении права и государства. - М.: Изд-во РАГС. 2000.- 303c.

25. Першиц А. И. Проблемы нормативной этнографии. - В кн.: Исследования по общей этнографии. - М., 1979. - 564c.

26. Рабинович П.М. Социалистическое право как ценность. - Львов, 1985. - С. 38-47;

27. Русско-башкирский словарь / Под ред. Н.К. Дмитриева. - М.: ГИИиНС, 1954. - 958 с.

28. Русско-индонезийский словарь / Под ред. Шахрула Шарифа. - М.: СС, 1972. - 624c

29. Русско-кабардино-черкесский словарь / Б.М. Карданов, А.Т. Бичоев. - М.: СС, 1955.- 435c.

30. Русско-китайский и китайско-русский словарь. - М.: Русс. яз., 1999. - 196с.

31. Русско-малазийский словарь / Под ред. В.А. Погадаева. - М.: Русс. яз., 1986. - 502c.

32. Русско-марийский словарь / Редкол. И.С. Ралкин (главред). - М.: СЭ, 1966. - 848с.

33. Русско-ногайский словарь / Под ред. Баскакова И.А. - М.: Гос. изд-во иностр. словарей, 1956. - 734 с.

34. Русско-таджикский словарь / Под ред. М.С. Асимова. -М.: Русс. яз., 1985. - 1279 с.

35. Русско-узбекский словарь / Под ред. Р. Абдурахманова. - М.: ГИИС, 1954. - 1047c.

36. Русско-урду словарь / Под ред. Зоэ Ансарии, Л.М. Померанцева. - М.: ГИИС, 1959. - 1135с.

37. Русско-хакасский словарь / Под ред. Д.И. Чанкова. - М.: Гос. изд-во иностр. словарей, 1961. - 967с.

38. Русско-хинди словарь / Под ред. В.М. Бескровного. - М.:ГИИС, 1957. - 1376 с.

39. Русско-якутский словарь / Под ред. П.С. Афанасьева, Л.Н. Харитонова. - М.: СЭ, 1968. - 768 с.

40. Семенов Ю. И. Формы общественной воли в доклассовом обществе: табуитет, мораль и обычное право // Этнографическое обозрение. - 1997. - № 4. - С. 34-38

41. Стучка П. Классовое государство и гражданское право / Социалистическая академия. Секция права и государства. M.,1924. - 78 c.

42. Уфимцева А.А., Азноурова Е.С., Кубрякова Е.С. Лингвистическая сущность и аспекты номинации // Языковая номинация (общие вопросы). - М, 1977. - С. 7-98

43. Фасмер М. Этимологический словарь русского языка: Т. 3. - М., 1987. - 656 с.

44. Фоли Д. Энциклопедия знаков и символов. - М.: Вече, АСТ, 1997. - 229 с.

45. Черных, Е. Н. Структура нормативной системы в древних обществах (методологический аспект) / Е. Н. Черных, А. Б. Венгеров // От доклассовых обществ к раннеклассовым / отв. ред.: Б. А. Рыбаков . - М. : Наука, 1987 . - С. 23-38

46. Шевцов С. К пониманию права в архаичных обществах // Антропологія права: філософський та юридичний виміри (стан, проблеми, перспективи): Статті учасників восьмого Міжнародного «круглого столу» (м. Львів, 7-8 грудня 2012 року). - Львів : Галицький друкар, 2013. - С. 553-569.

\section{References (transliterated):}

1. Alfred Toth Etymological Dictionary of Hungarian (EDH). - Hague: Mikes International, 2007. - 792 p.

2. Björn Collinder Fenno-Ugric Vocabulary. An Etymological Dictionary of the Uralic Languages. - Stockholm: Almqvist \& Wiksells; Upplasa, 1953. - 546 r.

3. Chantraine P. Dictionnaire étymologique de la langue grecque. Histoire des mots. - Tome 1 A- $\Delta .-$ Paris: Klinksieck, $1968 .-1387$ r.

4. Ernout A., Meillet A. Dictionnaire Etymologique de la Langue Latin. - Paris, 1979. - 434 r.

5. Mayhofer M. A. Concise Etymological Sanskrit Dictionary. - Bd 1. - Hdlb., 1956. - 975 r.

6. Abaev V.I. Istoriko-etimologicheskii slovar' osetinskogo yazyka. - M.: Izd-vo AN SSSR, 1958. - $350 \mathrm{~s}$.

7. Alekseev S.S. Problemy teorii prava: T. 1. - Sverdlovsk, 1972. - S. 30; 395s.

8. Baskanov I.A. Russko-karakalpakskii slovar'. - M.: SE, 1967. - 1124s.

9. Vengerov A.B. Teoriya gosudarstva i prava: Uchebnik dlya yuridicheskikh vuzov. - M.: Yurisprudentsiya, $2000 .-528 \mathrm{~s}$.

10. Voskanyan G.A. Russko-persidskii slovar'. - M.: Russ. yaz.,1986. - 832c.

11. Zhukova A.N. Russko-koryakskii slovar'. - M.:SE, 1967. - 749s.

12. Kandelaki T.L. Semantika i motivirovannost' terminov. - M.: Nauka, 1977. - 167 s.

13. Klimovich L.I. Kniga o Korane, ego proiskhozhdenii i mifologii. - M.:Politizdat, 1988. - 298s.

14. Koran / Per. i koment. I. Yu. Krachkovskogo. - M.: Nauka, 1986. - 298 s. 
DOI: $10.7256 / 1811-9018.2015 .7 .8962$

При цитировании этой статьи сноска на dоі обязательна

Правоведение

15. Krasheninnikova N.A. Istoriya prava Vostoka: Kurs lektsii. - M.: Izd. Rossiiskogo otkrytogo un-ta, 1994. - 121s.

16. Lebedev K.A., Yatsevich L.S., Kamenina Z.M. Russko-afganskii slovar'. - M.: SE, 1973. - 872s.

17. Lukovskaya D.I. U istokov pravovoi mysli Drevnei Gretsii // Izvestiya vysshikh uchebnykh zavedenii. Seriya: "Pravovedenie". - 1977 - №1. - S.75-84

18. Mal'tsev G. V. Pyat' lektsii o proiskhozhdenii prava i gosudarstva. - M.: Izd-vo RAGS. 2000.-303c.

19. Pershits A. I. Problemy normativnoi etnografii. - V kn.: Issledovaniya po obshchei etnografii. - M., 1979. - 564c.

20. Rabinovich P.M. Sotsialisticheskoe pravo kak tsennost'. - L'vov, 1985. - S. 38-47;

21. Semenov Yu. I. Formy obshchestvennoi voli v doklassovom obshchestve: tabuitet, moral' i obychnoe pravo // Etnograficheskoe obozrenie. - 1997. - № 4. - S. 34-38

22. Stuchka P. Klassovoe gosudarstvo i grazhdanskoe pravo / Sotsialisticheskaya akademiya. Sektsiya prava i gosudarstva. - M.,1924. $-78 \mathrm{~s}$.

23. Ufimtseva A.A., Aznourova E.S., Kubryakova E.S. Lingvisticheskaya sushchnost' i aspekty nominatsii // Yazykovaya nominatsiya (obshchie voprosy). - M, 1977. - S. 7-98

24. Fasmer M. Etimologicheskii slovar' russkogo yazyka: T. 3. - M., 1987. - $656 \mathrm{s.}$

25. Foli D. Entsiklopediya znakov i simvolov. - M.: Veche, ACT, 1997. - 229 c.

26. Chernykh, E. N. Struktura normativnoi sistemy v drevnikh obshchestvakh (metodologicheskii aspekt) / E. N. Chernykh, A. B. Vengerov // Ot doklassovykh obshchestv k ranneklassovym / otv. red.: B. A. Rybakov . - M. : Nauka, 1987 . - S. 23-38

27. Shevtsov S. K ponimaniyu prava v arkhaichnykh obshchestvakh // Antropologiya prava: filosofs'kii ta yuridichnii vimiri (stan, problemi, perspektivi): Statti uchasnikiv vos'mogo Mizhnarodnogo «kruglogo stolu» (m. L'viv, 7-8 grudnya 2012 roku). - L'viv : Galits'kii drukar, 2013. - S. 553-569. 